\title{
The Virtual Learning Media in Indonesia Language Class during Pandemic
}

\author{
Siti Sulistyani Pamuji ${ }^{1^{*}}$ \\ ${ }^{1}$ Indonesia Education Department, Universitas Borneo Tarakan, Tarakan, Indonesia \\ Corresponding Author*Email: sitisulistyani@borneo.ac.id
}

\begin{abstract}
The covid-19 pandemic drives education to be shifted from face-to-face to online learning. This condition initiated research, which aim was to find out how the Indonesia Language class was held and students' response. This type of research uses qualitative research conducted at the University of Borneo Tarakan. In this study, the researchers carried out the stages of Miles and Huberman in analyzing the data. In data reduction, researchers select, focus, simplify, make abstracts, transform the data obtained and observation sheets, survey results, and interviews with Indonesian lecturers and students. The results showed that based on the results obtained from students and lecturers in online learning other than e-learning (Borneo E-Learning, which is used at the University of Borneo Tarakan), social media has students often use. Online learning carried out by lecturers at the University of Borneo Tarakan in the Indonesian language course is still dominated by using the WhatsApp application, which is $29 \%$, then zooming by $26 \%$, Google Meet as much as $11 \%$, telegram, email as much as $10 \%$, video media $9 \%$ and text or audio as much as $5 \%$. The online learning model design in the Indonesian language course at the University of Borneo Tarakan uses online learning (online method) with various online learning media applications with the PPE model, namely material delivery, material deepening, and evaluation.
\end{abstract}

Keywords: Online Learning Media, Indonesia Language Class,

\section{INTRODUCTION}

Currently, Indonesia is one of the countries affected by the Covid-19 pandemic, which has occurred almost worldwide. The Covid-19 virus is a disease that can be fatal due to viral infection [1] [2]. The Covid-19 pandemic is very easy and very fast to spread, causing several public appeals, such as calls for the Work from Home (WFH) movement and calls for online learning carried out by almost all universities in Indonesia.

Online learning is learning that is carried out face-toface through the available application programs. Online learning was carried out at various universities as a forum for the implementation of teaching and learning activities to continue to be carried out, even though lecturers and students were still at home [3]. There are so many supporting facilities for online learning. The Indonesian Ministry of Education and Culture prepares various online learning needs ranging from Google for Education, Google Classroom, etc. It makes it easy for lecturers and students to carry out learning [4]. The media currently used in online learning primarily uses video zoom and google meet to replace the face-to-face learning process.

Various online learning applications prepared by the government, private sector, and universities choose lecturers to provide effective learning for students. The University of Borneo Tarakan provides the Borneo ELearning platform, which functions as a learning tool for students. This alternative is to conduct online-based learning, especially in the Indonesian General Compulsory Course (MKWU).

The Indonesian language course is one of the MKWU courses at the University of Borneo Tarakan. The learning achievement in this course is that students can communicate well both orally and in writing. On the other hand, analytical power's ability to solve problems faced, predominantly local and border issues, is another ability demanded by graduate users. Therefore, it is 
necessary to make efforts by UBT to improve the communication skills of students' analytical thinking can be applied through language skills in Indonesian language courses.

Lecturers must be able to design learning that was initially face-to-face learning, turned into online learning. There are problems in conducting online learning in using learning models, including teaching methods and media that lecturers must prepare and internet quota for students and poor internet access, especially for students in border areas far from internet access.

From the various descriptions above, it is necessary to conduct research related to online learning models' design during the Covid-19 Pandemic in the Indonesian language course for students at the University of Borneo Tarakan. With this research, it is hoped that it can produce findings to see how the learning model design is applied by lecturers who teach Indonesian Language courses at the University of Borneo Tarakan.

\section{METHOD}

In this study, researchers carried out Miles and Huberman's stages in analyzing data [5] [6]. In data reduction, the researcher selects, focuses, simplifies, makes abstracts, and transforms the data obtained and the observation sheets, and the results of surveys and interviews with Indonesian lecturers and students. In the second stage, the researcher presented the data using tables and diagrams and explained the gained data. Furthermore, the researchers reviewed the research findings to draw conclusions and verification regarding the design of online learning models during the Covid-19 Pandemic in the Indonesian language course for students at the University of Borneo Tarakan. They were able to produce new learning model designs that lecturers could apply for more good.

The data used in research are primary data and secondary data. Primary data was obtained directly from the first source, while secondary data, namely data obtained indirectly. To get the data needed in this study, the researchers used several data collection instruments, namely, field observation instruments and interview documents.

[7] Research data collection techniques are data collected for this study, namely qualitative data in online learning model documents during the Covid-19 Pandemic period in the Indonesian language course for students at the University of Borneo Tarakan. This data is obtained through observation, documentation, and interviews.

This research is a qualitative descriptive study. Miles and Huberman explained that this study's design presented data in the form of descriptions using more words than in presenting data in the form of numbers [5] [6].

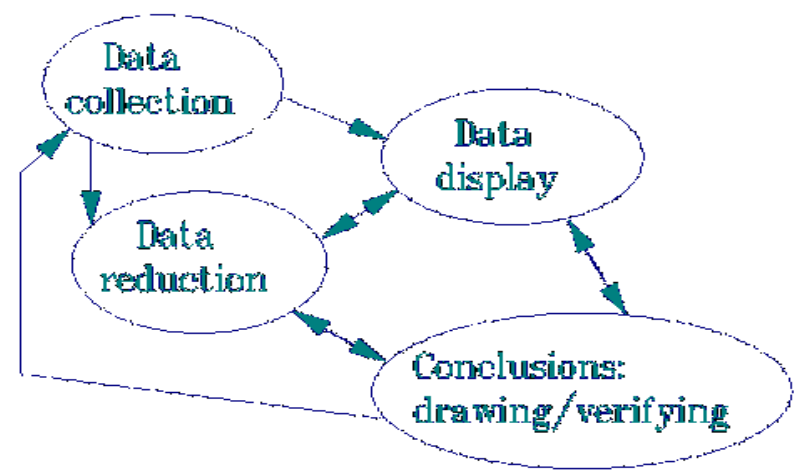

Figure 1 M\&H's Component of Data Analysis

\section{RESULT AND DISCUSSION}

\subsection{Online Learning Survey on Indonesia Language Class}

The online learning model's research results in the Indonesian language course show that during the Covid19 pandemic, the learning model used by lecturers switched from a face-to-face learning model to an online learning model. Since the Covid-19 pandemic, online learning has become an obligation for lecturers to keep the learning going. It adds to new challenges for every education actor in Indonesia, especially lecturers, in preparing online learning that is suitable for application to students [3] [4].

A survey conducted in online learning for lecturers and students in the Indonesian language course shows that the model used by lecturers in online learning must pay attention to media, methods, and materials. [8] The survey results showed that $40.3 \%$ of University of Borneo Tarakan students in the Indonesian language course agreed with online learning as an alternative to academic activities during the Covid-19 pandemic. Students stated through online learning; they can study as usual and not miss the lecture material and flexible time. [9] Online learning was also not fully approved by students because $53.7 \%$ of students gave disagreement and stated that the availability of internet quota was the most significant difficulty experienced by students. Another issue was learning devices such as laptops. The level of understanding, the atmosphere at home, and the environment also determine online learning effectiveness at home [10].

In addition to student interest, $51.9 \%$ of students' assessment of the learning process's online learning model is quite good. In this online learning, the lecturer makes teaching materials for online learning. [11] Online lecture activities occur through various online learning 
applications such As Whatsapp, Zoom, Telegram, Video, Text / Audio, Google Meet, and Email. Following are the results of a survey of media that. Lecturers often use in online learnino

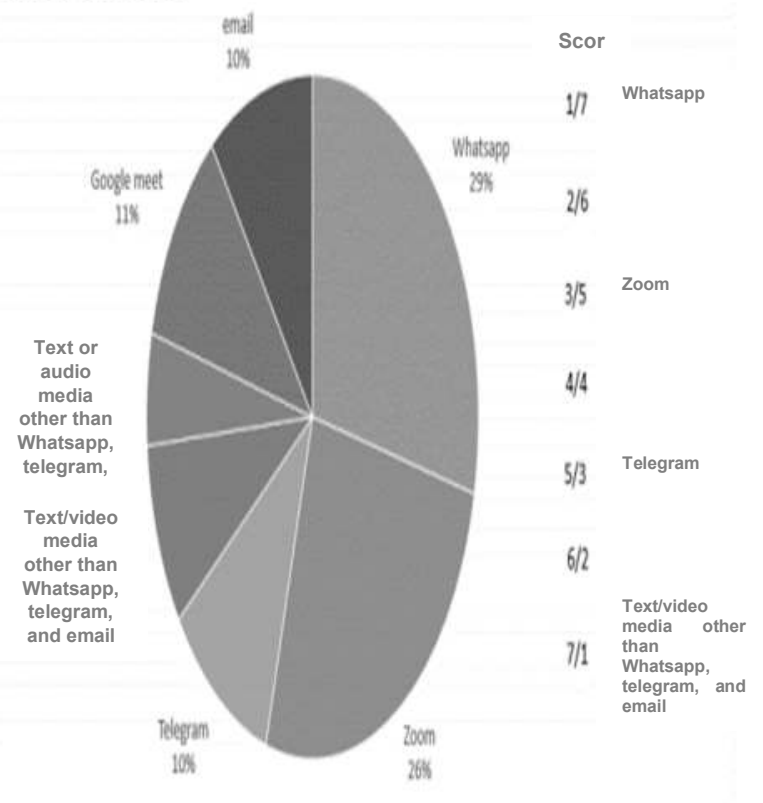

Figure 2 M\&H's Component of Data Analysis

Based on the results obtained from students and lecturers that in online learning, besides e-learning (Borneo E-Learning which is used at the University of Borneo Tarakan), there are social media that students often use. Online learning carried out by lecturers at the University of Borneo Tarakan in the Indonesian language course is still dominated by using the WhatsApp application, which is $29 \%$, then zooming by $26 \%$, google meet as much as $11 \%$, telegram, email as much as $10 \%$, video media $9 \%$ and text or audio as much as $5 \%$.

\subsection{Online Learning Model Design}

After gaining the online learning survey results in using applications in online learning in the Indonesian language course at the University of Borneo Tarakan, an online learning model design was produced, namely the PPE (Material Delivery, Material Depth, and Evaluation) model [12] [13] [14]as follows:

\subsubsection{Delivery of Material}

In terms of delivering material, the lecturer's online learning model is using 2 types, synchronously and asynchronously [4]. Synchronous learning is a learning interaction between lecturers and students simultaneously, using video conferencing or chat technology. Media used such as Zoom, Google Meet, Webex, MS teams, etc.

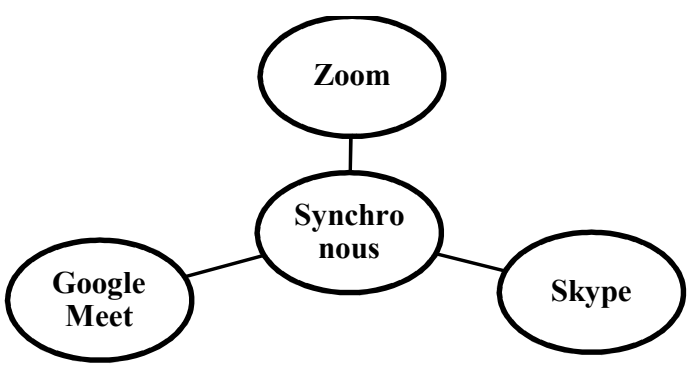

Figure 3 Synchronous Media

Meanwhile, asynchronous, namely, the lecturer prepares the material in advance. The learning interactions are carried out flexibly and not necessarily simultaneously, for example, using a discussion forum or independent study/assignment to students through elearning. The media used are E-modules, Slide, Youtube, Module, and internet resources.

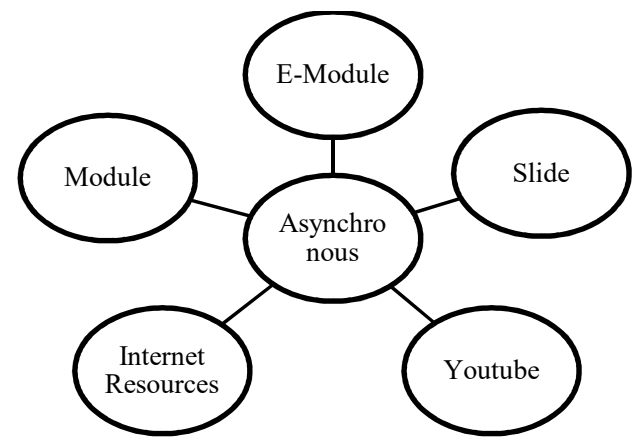

Figure 4 Asynchronous Media

\subsubsection{Deepening of the Material}

In deepening material, media used by lecturers was the WA group, Telegram Group, Borneo E-learning (BEL). In the material deepening stage, the lecturer uses a combination of online learning processes, for example, such as the WhatsApp group, which is making class grub on WhatsApp and inviting all class members. The lecturer can upload learning materials and lecture assignments. Material and assignments were shared with class accounts created on WhatsApp. Students can download materials and assignments through their respective stores. Students can also conduct consultation sessions via the group's WhatsApp.

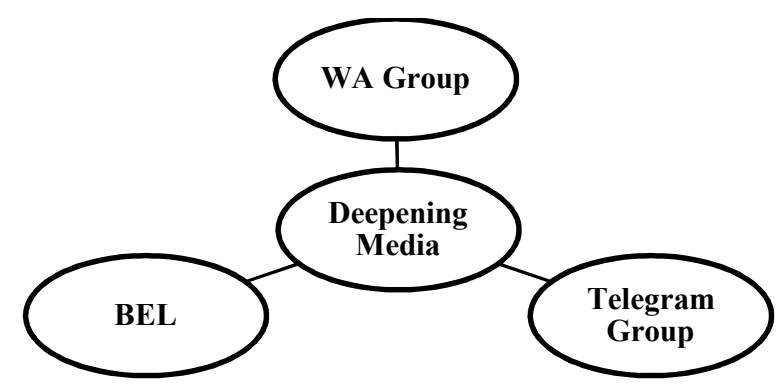

Figure 5 Deepening Media 


\subsubsection{Assessment}

At the evaluation stage, online learning applications can be made using several models such as Google Form, Kahoot, Quizizz, and BEL. Evaluation is carried out at the end of learning, assignments, quizzes, midterm assessments, and final-term assessments.

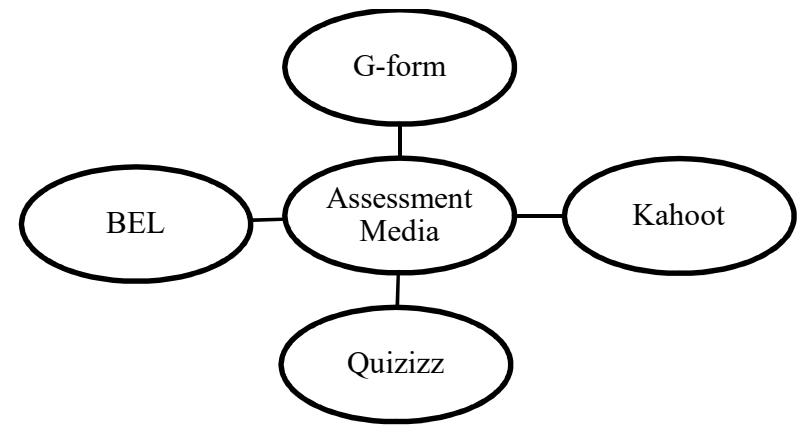

Figure 6 Assessment Media

The analysis results indicated that the design of the online learning model in the Indonesian language course at the University of Borneo Tarakan uses online learning as a combination of various applications (online method) [12] [14] [15]. Online learning is not limited by time and space, which does not require students to study in the classroom. Based on the survey results that have been carried out, it has produced an online learning model design applied by lecturers with the PPE model, including material delivery, deepening of the material, and evaluation.

\section{CONCLUSIONS}

Students agree that online learning is an alternative to academic activities carried out during the Covid-19 pandemic. Still, online learning obstacles were met, such as internet credit, limited internet connection, lack of learning devices, level of material understanding, home atmosphere, and the surrounding environment that does not support determining online learning effectiveness at home.

The online learning media applications most widely used by lecturers other than BEL (Borneo E-Learning) include Whatsapp, Zoom, Google Meet, Telegram, and others.

The online learning model design in the Indonesian language course at the University of Borneo Tarakan uses online learning (online method) with various applications of online learning media with the PPE model, namely material delivery, material deepening, and evaluation.

\section{AUTHOR'S CONTRIBUTIONS}

Siti Sulistyani Pamuji was the compiler of the research proposal, prepared the instruments, collected data, analyzed the research data, and wrote it.

\section{ACKNOWLEDGMENTS}

The author's gratitude goes to the Chancellor of the University of Borneo Tarakan and LP2M, who have provided funding support for DIPA Borneo Tarakan University so that this research can be completed properly. Also, Dr. Suyadi, M.Ed., as Dean of FKIP UBT, supported the author in the research process. Especially students who teach the Indonesian Language course Odd Semester Academic Year 2020/2021 Universitas Borneo Tarakan who have participated in this research

\section{REFERENCES}

[1] Allianz, "Allianz Indonesia," 11 March 2020. [Online]. Available: https://www.allianz.co.id/explore/detail/yukpahami-lebih-jelas-arti-pandemi-pada-covid19/101490. [Accessed 7 May 2020].

[2] Warsita, Teknologi Pembelajaran dan Aplikasinya, Jakarta: Raja Grafindo Persada, 2008.

[3] D. Afrianto, "RiauPos.co," Riau Pos, 13 July 2020. [Online]. Available: https://riaupos.jawapos.com/citizenjurnalis/13/07/2020/234850/pembelajaran-daringdan-3-m-media-metode-dan-materi.html.

[Accessed 8 November 2020].

[4] Hakiman, "IAIN Surakarta," IAIN Surakarta, 17 January 2020. [Online]. Available: https://iainsurakarta.ac.id/\%EF\%BB\%BFpembelajarandaring/. [Accessed 7 May 2020].

[5] Sugiono, Metode Penelitan Pendidikan, Bandung: Alfabeta Press, 2015.

[6] A. R. Zainal , Metode Penelitian Pendidikan, Yogyakarta: Andi Press, 2019.

[7] R. B. Johnson and L. Christense, Educational Rersearch: Quantitative, Qualitative, and Mix Approaches, 6th Edition ed., Singapore: SAGE Publications, Inc, 2017.

[8] N. Kock, . J. Verville and V. Garza, "Media Naturalness and Online Learning: Findings Supporting Both the Significant- and NoSignificant-Difference Perspective," Decision Sciences Journal of Innovative Education, vol. 5, no. 2, p. 333, 2005.

[9] G. Salmon , B. Ross , E. Pechenkina and A.-M. Chase, "The space for social media in structured 
online learning," Research in Learning Technology , vol. 23, 2015.

[10] E. T. Sofian, Metode Peneltiian Survei, Jakarta: Pustaka LP3ES, 2012.

[11] F. L. Weiser and H. Friedman, "Using Social Media Technologies to Enhance Online Learning," Journal of Educators Online, vol. 10, no. 1, p. 18, 2021.

[12] R. J. Bruce , W. Marsha and Emely Calhoun, Models of Teaching, Boston: Pearson Allyn and Bacon Publisher, 2009.

[13] Rusman, Model-Model Pembelajaran (Mengembangkan Profesionalisme Guru), Jakarta : PT. Raja Grafindo Persada, 2014.

[14] S. Toeti and Winataputra, Strategi Belajar Mengajar, Tangerang: Universitas Terbuka, 1997.

[15] K. P. d. Kebudayaan, Undang-Undang No.20 Tahun 2003 Tentang Sistem Pendidikan Nasional pasal 1 ayat 20, Jakarta: Direktorat Jendral Manajemen Pendidikan dasar dan Menengah, 2003. 